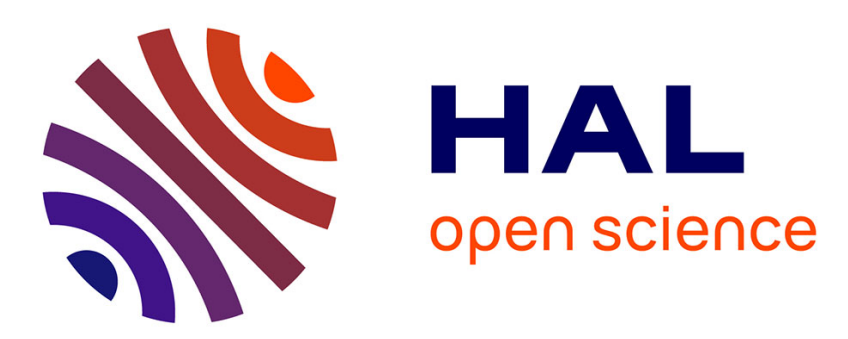

\title{
Urgently Needed for Policy Guidance: An Operational Tool for Monitoring the COVID-19 Pandemic
}

Stéphane Luchini, Miriam Teschl, Patrick Pintus, Mickael Degoulet, C. Baunez, Jean-Paul Moatti

\section{- To cite this version:}

Stéphane Luchini, Miriam Teschl, Patrick Pintus, Mickael Degoulet, C. Baunez, et al.. Urgently Needed for Policy Guidance: An Operational Tool for Monitoring the COVID-19 Pandemic. 2020. hal-02526456

\section{HAL Id: hal-02526456 https://hal-amu.archives-ouvertes.fr/hal-02526456}

Preprint submitted on 31 Mar 2020

HAL is a multi-disciplinary open access archive for the deposit and dissemination of scientific research documents, whether they are published or not. The documents may come from teaching and research institutions in France or abroad, or from public or private research centers.
L'archive ouverte pluridisciplinaire HAL, est destinée au dépôt et à la diffusion de documents scientifiques de niveau recherche, publiés ou non, émanant des établissements d'enseignement et de recherche français ou étrangers, des laboratoires publics ou privés. 


\section{amse}

école d'économie d'aix-marseille

aix-marseille school of economics

\section{Working Papers / Documents de travail}

\section{Urgently Needed for Policy Guidance: An Operational Tool for Monitoring the COVID-19 Pandemic}

Stéphane Luchini Miriam Teschl

Patrick A. Pintus

Mickael Degoulet

Christelle Baunez

Jean-Paul Moatti 


\title{
Urgently Needed for Policy Guidance: An Operational Tool for Monitoring the COVI D-19 Pandemic
}

\author{
S. Luchini, M. TeschI, P.A. Pintus, M. Degoulet, C. Baunez, J.-P. Moatti, ${ }^{1}$ \\ Aix-Marseille University, CNRS, EHESS
}

March 30, 2020

\begin{abstract}
The radical uncertainty around the current COVID19 pandemics requires that governments around the world should be able to track in real time not only how the virus spreads but, most importantly, what policies are effective in keeping the spread of the disease under check. To improve the quality of health decision-making, we argue that it is necessary to monitor and compare acceleration/deceleration of confirmed cases over health policy responses, across countries. To do so, we provide a simple mathematical tool to estimate the convexity/concavity of trends in epidemiological surveillance data. Had it been applied at the onset of the crisis, it would have offered more opportunities to measure the impact of the policies undertaken in different Asian countries, and to allow European and North-American governments to draw quicker lessons from these Asian experiences when making policy decisions. Our tool can be especially useful as the epidemic is currently extending to lower-income African and South American countries, some of which have weaker health systems.
\end{abstract}

Keywords: Acceleration; Convexity; COVID-19; Data Dashboard; Detection of Infectious Diseases; Public Health Policy; Sensitivity.

JEL Classification: 118; H12.

1 C. Baunez and M. Degoulet: INT, Aix-Marseille University, CNRS, christelle.baunez@univ-amu.fr, mickael.degoulet@univ-amu.fr; J.-P. Moatti : IMéRA, Aix-Marseille University, jean-paul.moatti@ird.fr; Luchini, Pintus, and Teschl: AMSE, Aix-Marseille University, CNRS and EHESS, stephane.luchini@univ-amu.fr, miriam.teschl@ehess.fr, patrick.pintus@univ-amu.fr. 


\section{Introduction: Misguided Diagnostics about the Pandemic Dynamics?}

Laypeople and policymakers alike are currently, all around the world, scrutinizing and commenting on daily data related to the quickly expanding pandemic of COVID-19. This new strain of coronaviruses is at the origin of an outbreak that started in China, possibly as early as November 17, 2019, when patient zero was supposedly contaminated. The World Health Organization was alerted on this outbreak on December 31 and the spread of the virus has since then gone global, reaching 169 countries by now. Although we live in a globalized and interconnected world that fuels the dissemination of the virus, countries that have been exposed to COVID-19 at about the same time are finding themselves in quite different health situations today.

While at first infection rates and policy responses in China were for some time at the center of the attention, the focus has now shifted to South Korea, where the onset of the outbreak was reported only a few days before first infections were registered in Europe and the US. On February $1^{\text {st }}$, South Korea reported 12 cases, while Germany and the US reported 7, France 6, Italy 3, UK 2 and Spain 1. However, the pandemic dynamics that followed happen to be strikingly different.

Figure 1 reports the total confirmed cases of infection to COVID-19 and shows that while South Korea was able to curb the evolution of the pandemic very early on, European countries did not. Since the very beginning of the outbreak, South Korea implemented a very active strategy by testing about 350,000 people out of the 50 -million population (that is, about 7 persons in 1000), contact tracing and calls for social distancing. In contrast, a testing and contact tracing policy was not adopted in France, Italy and Spain, where the biggest step against the coronavirus was a China-like lockdown of the country, as late as March 9 for Italy, March 16 in Spain, March 17 in France, and March 24 in the UK.

As can be seen in Figure 1, South Korea managed to limit the increase of new cases from about March $1^{\text {st }}$ onwards, that is, about 6 weeks after the start of the outbreak. At about the same time, an increase in cases was already discernable in Italy. One week later, from March 8 onwards, the number of cases started to increase quickly in France and elsewhere. Hence, the global data that was available in early March showed that while the pandemic was spreading rapidly in Europe, it was already slowing down in South Korea, approaching an upper limit of total cases by mid-March. 


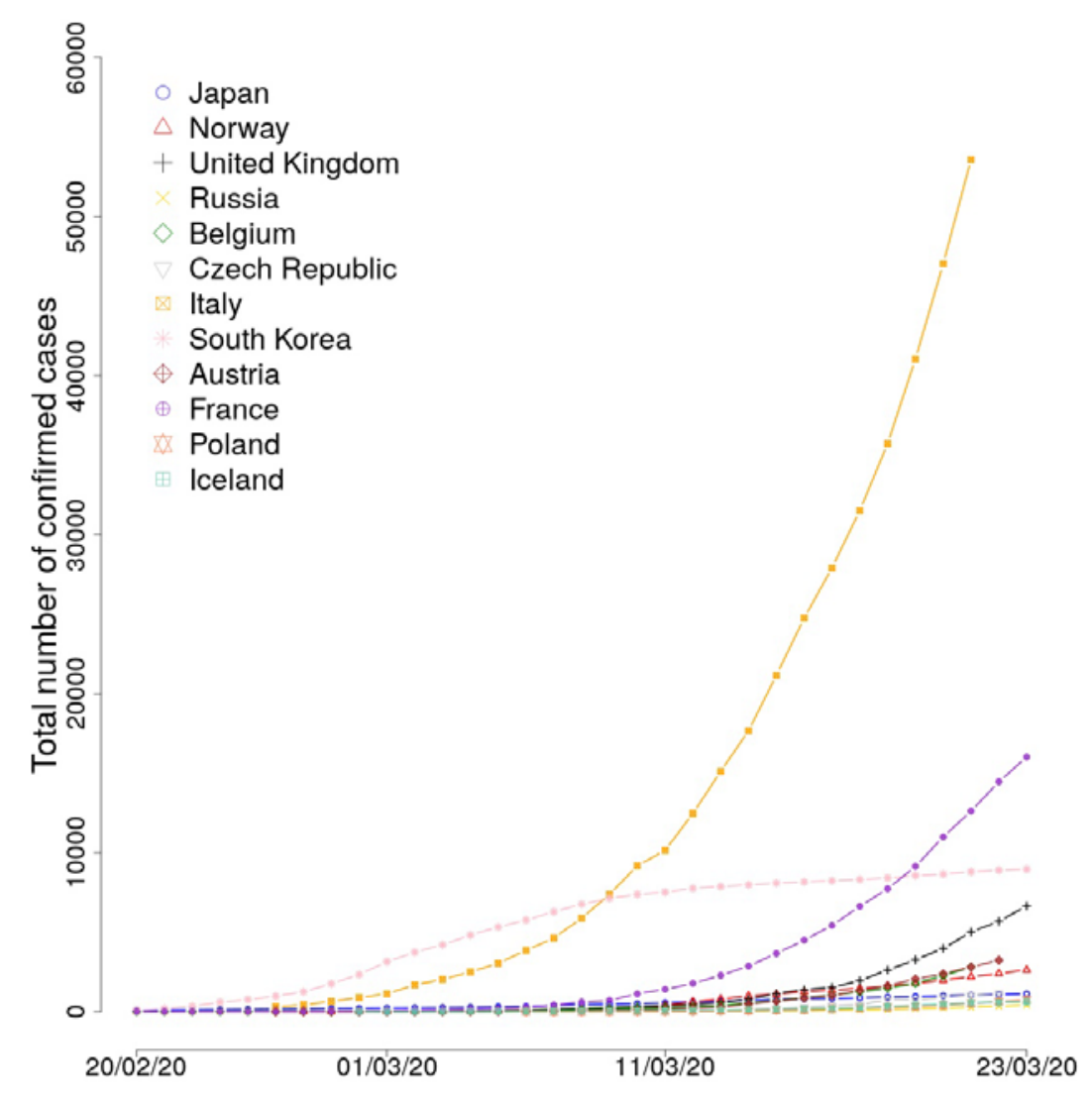

Figure 1 Total number of confirmed cases of COVID-19 in several countries over time Data source: https://ourworldindata.org/coronavirus

In view of the available data and international comparisons at that time, one may wonder why public authorities in charge of health policies outside China and South Korea and some other Asian countries showed some apparent inertia in taking early steps to curb the pandemic, and why they did not make those same and relatively cost-effective policy decisions, in comparison to a total lock-down.

One possible answer may be that decision-makers were impressed by the Chinese response and that advice from national medical and public health researchers (Wilder-Smith and Freeman 2020; Wu and McGoogan 2020) did not enough take into account lessons from the South Korean response. Indeed, it suggests that an appropriate analytical framework for real time interpretation of available data had been lacking. Although looking at the number of infected persons is right, its evolution over time in Figure 1 does not tell much about what should be done. Consequently, policy makers were and still are not able to detect soon enough whether harm is accelerating, or the pandemic is decelerating (at a sufficient speed) as a response to implementation of specific policies. Instead, policy makers often rely on 
forecasting models that are very sensitive to assumptions and are much less responsive than any real time evaluation procedures. ${ }^{2}$

\section{Methods: Detecting Acceleration of Harm in Real Time as a Major Tool for Decision- Making}

The alternative approach we advocate here involves thinking less in terms of predictions in situations where it is very difficult to get precise estimates of probabilities and outcomes. Instead, in the context of the COVID19 pandemic, decision-makers are confronted with radical uncertainty. When probabilities (and thus, scientifically speaking, any decision making under risk) are out of reach, such as when a novel infectious agent occurs, an alternative to fragile predictions is to make sure that society is exposed to limited losses (and to potentially unlimited gains), irrespective of which scenario finally materializes. A more appropriate framework for decision-making is then to think in terms of exposure to uncertainty. Following Taleb (2012), the idea is to use the simple mathematical properties of convexity/concavity, to interpret the information provided by epidemiological surveillance and to estimate within a short timeframe the impact of different policies and courses of action. ${ }^{3}$ Any crisis is "no business as usual" and requires some "out-of-the-box" thinking and engaging in protection/innovation strategies to test within a short time-horizon the impact of different policies and courses of action. It necessitates directed sensibilities to find approaches that, according to the valence of the event, need to save a maximum of harm or to spread gains as equally as possible. Ideally, no known and realizable branch of a decisiontree should be left unexplored and new, creative decisions should be put into place for trialand-error testing. ${ }^{4}$

In the context of real-time observation of ongoing pandemics, this means that one has to engage in an international comparison of policies and evaluate whether harm - here number of cases over time - accelerates (is convex) as a function of the policy response, within and across countries. Countries, where harm is or becomes concave as a function of

\footnotetext{
2 For example, Ferguson et al (2020, page 6): “For these interventions we therefore consider surveillance triggers based on testing of patients in critical care (intensive care units, ICUs)" (emphasis ours). See the review by Shen et al (2020) for limitations of such models. See also Wu, et al (2020) for a prototypical SusceptibleExposed-Infectious Recovered (SEIR) model.

3 Mathematically, convexity is measured by the Jensen gap and Bregman information. See Banerjee et al (2005). Those concepts can especially be used to compare the relative convexities of different trends.

4 The fact that such deceleration/concavity measures seem not to be part of the data dashboards of governments around the world possibly relates, we speculate, to preliminary results from ongoing experiments using animal and human subjects. In a forthcoming paper, Degoulet et al. (2020) report results showing that rats are sensitive to acceleration/convexity of gains and deceleration/concavity of losses, when confronted with options that differ along this dimension. However, such sensitivity is heterogeneous across animal subjects, which suggests that detecting acceleration/deceleration may not be natural for all individuals. Heterogeneity is confirmed by preliminary results from ongoing experiments with human subjects, whose sensitivity to acceleration/deceleration is however hampered by uncertainty.
} 
the policy taken, are supposed to have adopted the best practices, the ones to follow or adapt rapidly. We turn to this point in the next section.

\section{Results: Infected vs Tested Scatterplot as a Tool to Detect Acceleration of the COVID-}

\section{Pandemic}

In Figure 2 we report how the total number of confirmed cases responds to the total number of tested individuals in different countries. Data is national level data. We collected data on the total number of tested persons as well as the number of confirmed positive tests as published by daily reports from national health institutes and ministries of health on their websites. For most countries presented in this paper, we have data from the first detected case to about March 21-23, except France for which data stops on March 15. In appendix A, we give our sources and the time range for each country.

In the left panels a) we report raw data whereas in right panels b) we present the spline estimation of the relationship. This method is an easy computational way to fit a smooth curve (polynomial spline) to pairs of data values $\left(y_{i}, x_{i}\right)$ without any prior specification of a parametric functional form, and it provides both point and interval estimates. It is based on a local polynomial regression that uses Savitzky-Golay filter also known as a locally estimated scatterplot smoothing method in modern statistics (Savitzky and Golay, 1964, Harrel, 2015). The resulting curves can be used to describe the patterns of the data and to nowcast values of $y$ given $x$.

Data from South Korea - $1 \mathrm{a}$ and $1 \mathrm{~b}$ - show that public health policy is arguably on the right track since the response shows deceleration (i.e. concavity), as early as March $1^{\text {st }}$ after acceleration came to a halt. Looking at the data in this way would have probably been very useful in early March to decision-makers in Europe and elsewhere, because acceleration/deceleration of harm can be an important measure to guide public policy. $A$ somewhat similar pattern is followed by Lower Austria and Japan, as shown in panels 2 and 3. A less pronounced inflection point also appears in the curves that we report in panels 4 and 5 for the Czech Republic and Austria as a whole. By contrast, Norway, France and Italy panels 6 to 8 - seem to still be facing a situation in which the number of cases grows as fast as the number of persons tested: the graph shows a straight line for most of the sample. Even more worrying are the cases of Belgium, Poland, Russia, the UK and especially Iceland depicted in panels 9 to 13, which seem to follow a trajectory that is the reverse image of South Korea's: infections grow faster than tests, so that harm accelerates in spite of more testing. 

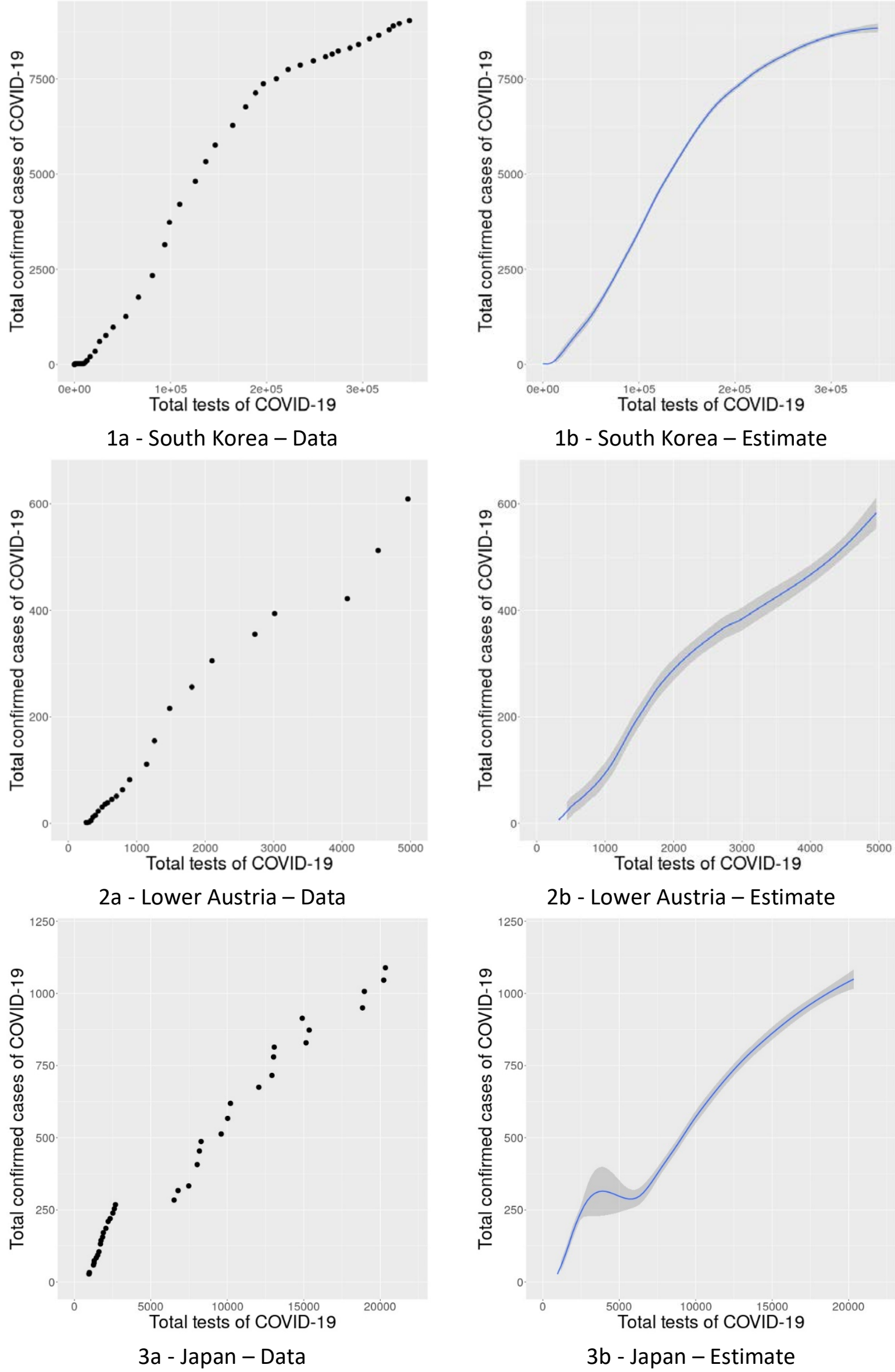

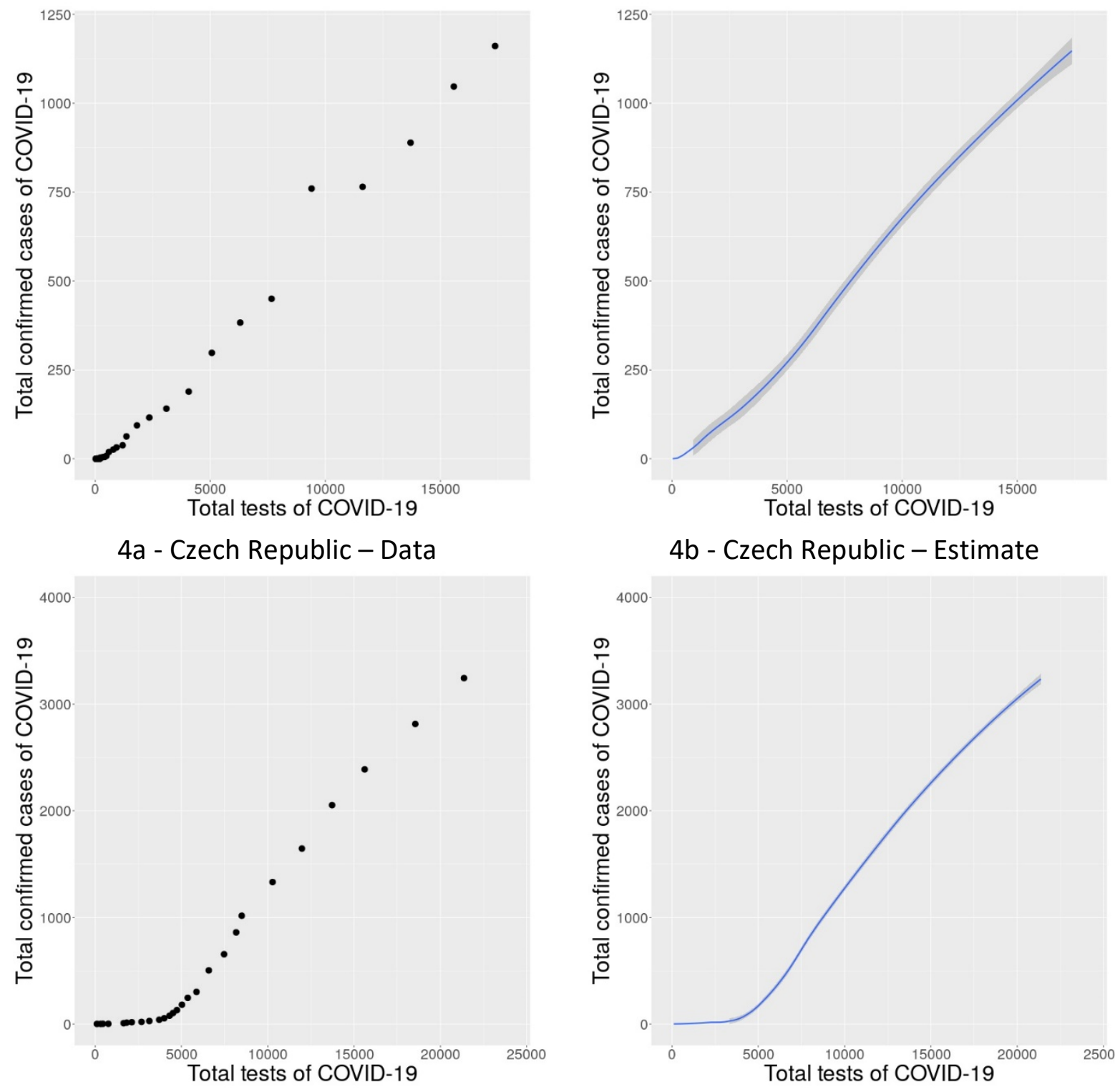

4b - Czech Republic - Estimate
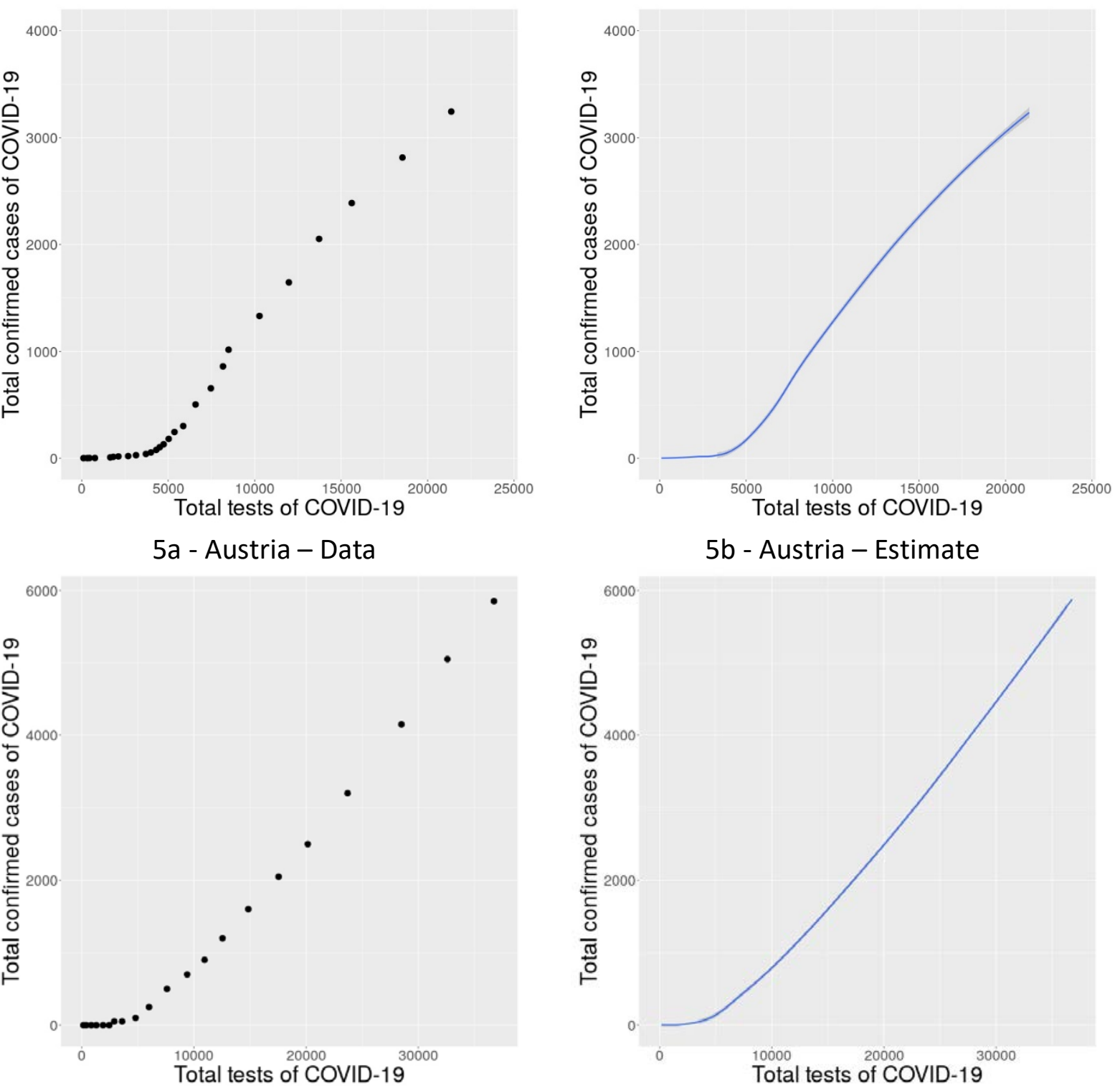

$6 a$ - France - Data

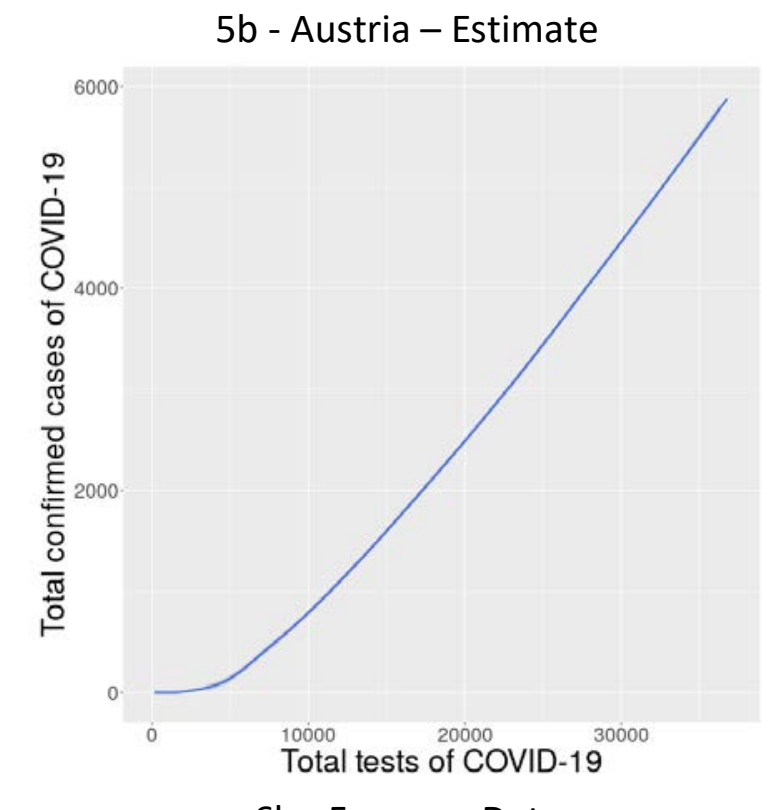



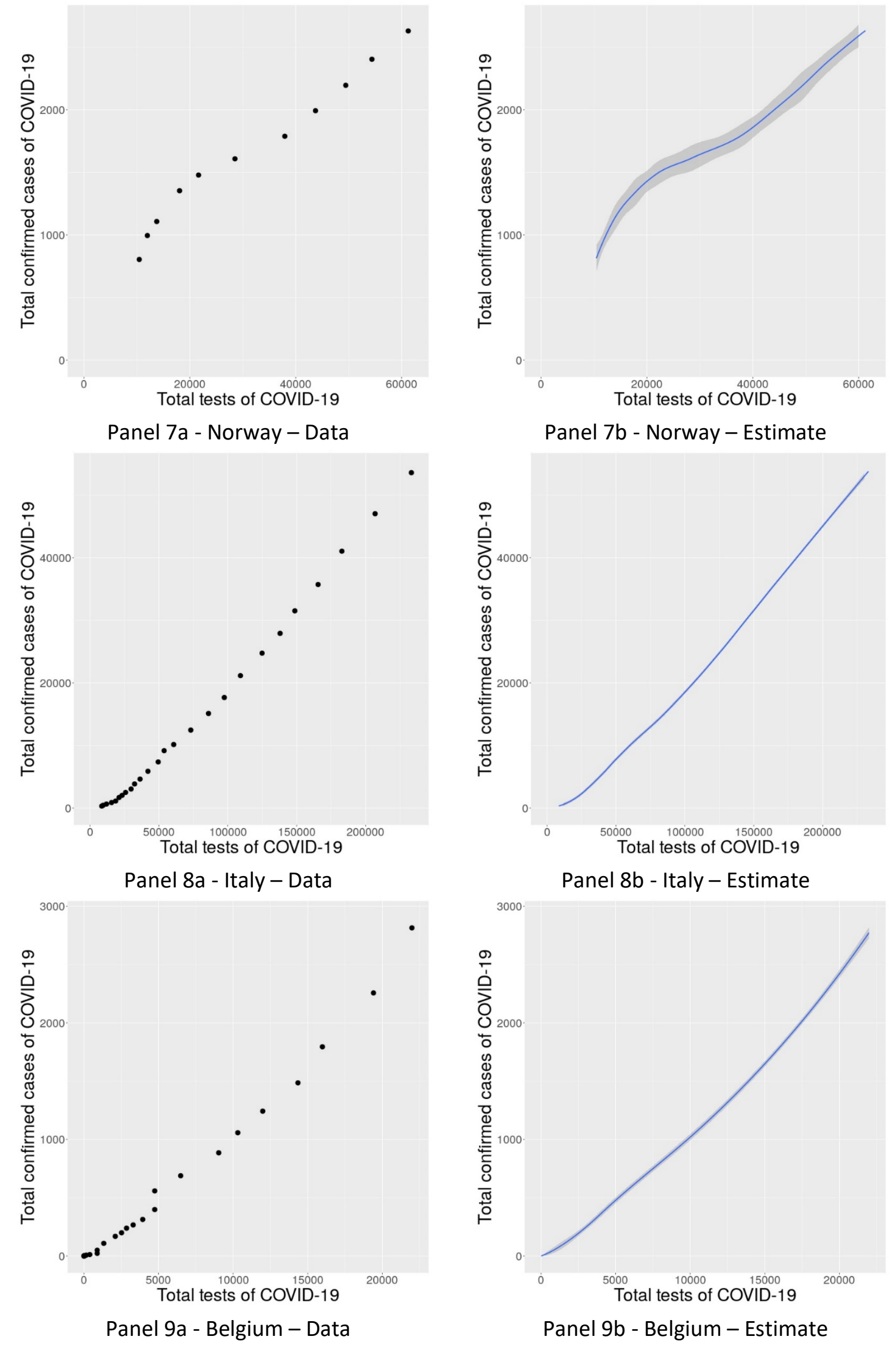

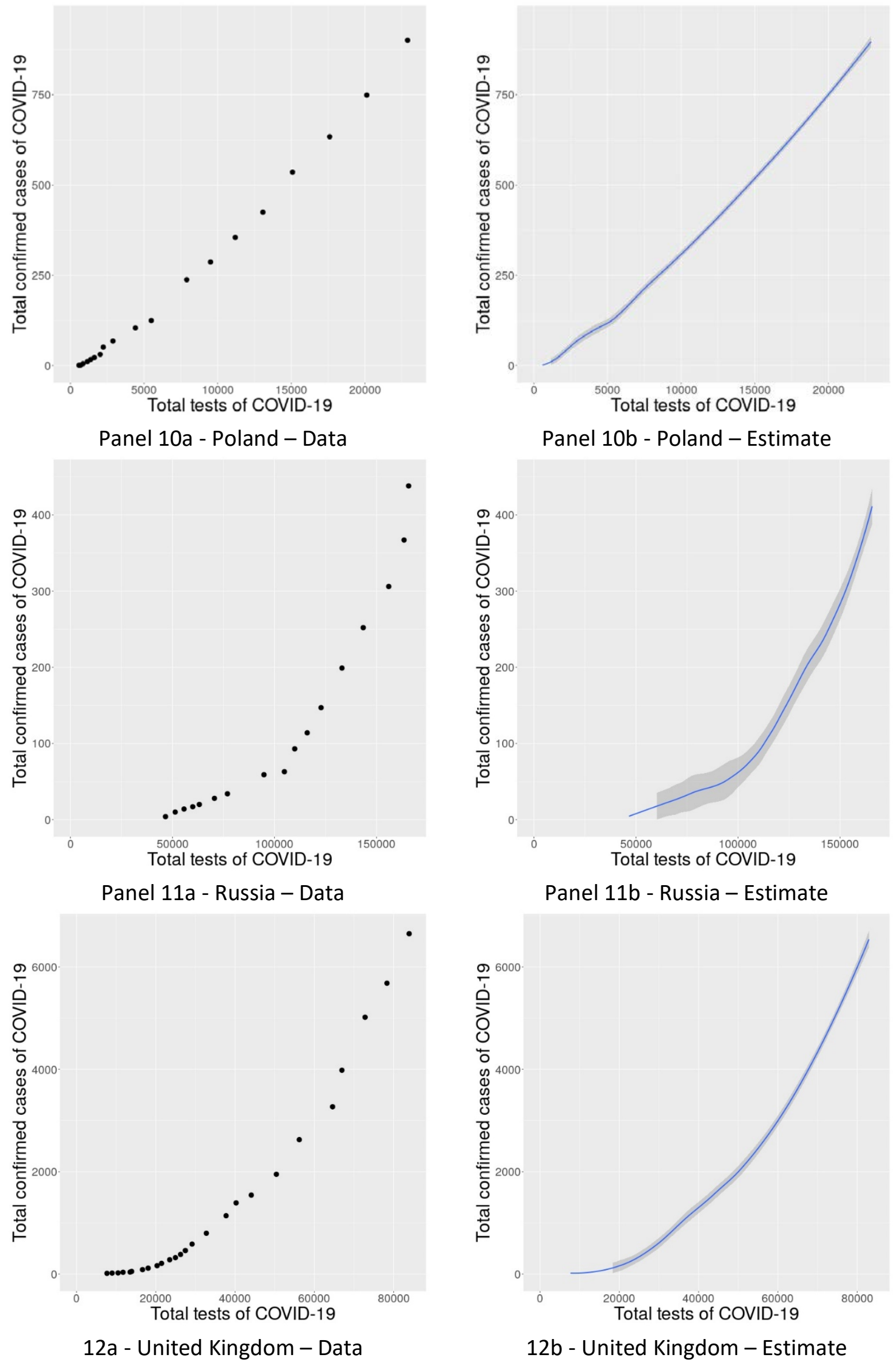

Panel 11b - Russia - Estimate

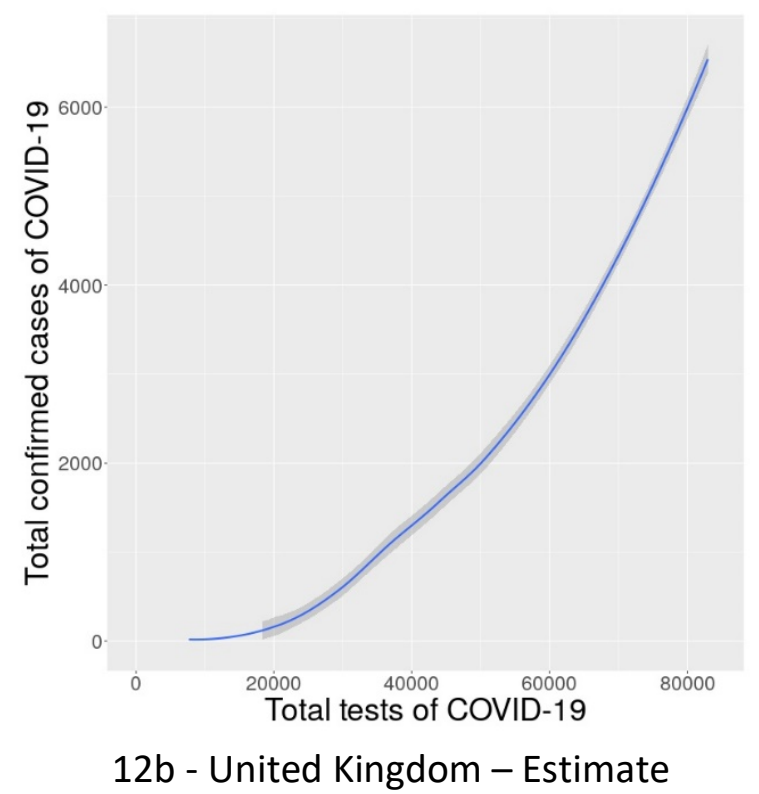



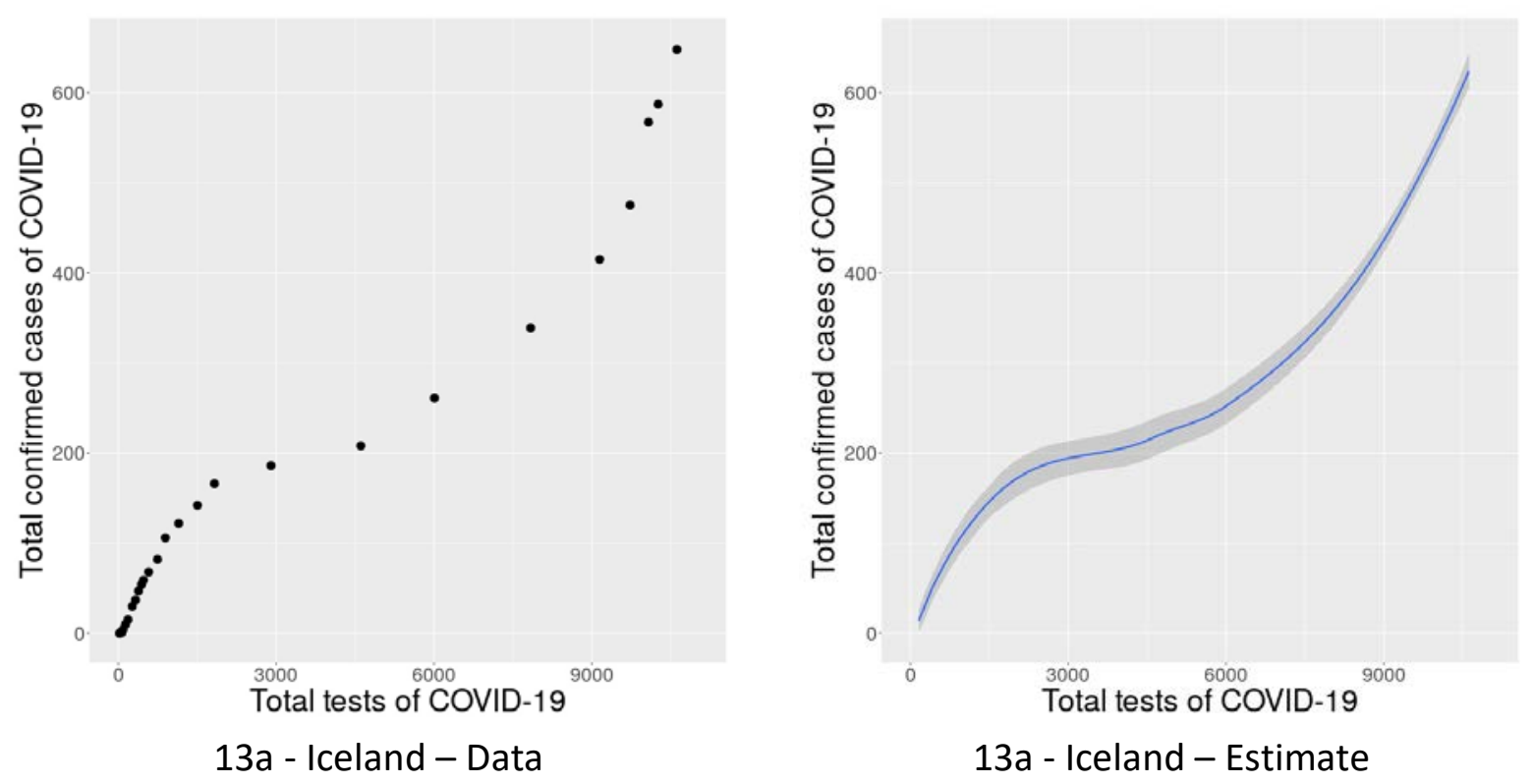

Figure 2: Scatterplot of total confirmed cases and total tests of the COVID-19 different countries, as of March 24, 2020. Left panels: raw data. Right Panels: loess estimation (authors).

Data source: see appendix A

\section{Discussion: what does Data Organized to Detect Acceleration/Deceleration of} Pandemic over Health Policy Response Tell Us?

Three main lessons can be drawn from our approach, exemplified in Figure 2. First, what is striking in panels $1 a-13 b$ is that even countries that imposed drastic measures such as closures of schools and universities, restaurants and bars, parks and playgrounds and all non-essential shops show almost no sign of being able to decelerate the pandemic. Countries like the region of Lower Austria appear to have been an exception for some time, but latest data points show that acceleration may quickly be back on track. The possibility to say so is indeed the advantage of a real time evaluation of the acceleration/deceleration of harm as we propose it.

Second, given the example of South Korea, we argue that countries failed to look at the data at the right moment in the right way, when they had to decide on the appropriate policy actions. In a counterfactual world where France, Italy, Belgium, Poland, Russia and the UK would have observed South Korea's experience through the lens of panel $1 a-1 b$, they could have inferred that South Korea's early testing and tracing policy had to be considered seriously. Massive early testing and precise contact tracing, as well as cooperation of the population in the compliance of social distancing was key to curbing the pandemic in South Korea, without a total lock-down of the country. However, even South Korea, as we see in 
panel $1 a-1 b$, is not yet fully protected from sliding into another acceleration phase - since the very last data points suggest a slight increase of confirmed cases over total tests.

Third, by comparing, for example, the UK data in Figure 1 with the data in panel 12a$12 b$, we clearly see that while the evolution of confirmed cases in the UK is growing in Figure 1 , it appears to be much less dramatic in comparison to other countries in view of how the acceleration dynamics is captured by panels $12 a-12 b$. On the other hand, Italy has the not been able to hamper the acceleration of the crisis. The case of Iceland (panel 13a-13b), which recently received some positive media coverage because of its aggressive testing policy, is also interesting from the perspective of our data: the Icelandic situation is still explosive despite testing. This clearly shows that a simple tracing statistic of confirmed cases is not enough to make informed policy decisions and that spline estimation of convexity/concavity brings added value for close monitoring of the epidemic ${ }^{5}$.

So far, we have focused on harm caused by the infectious disease and shown how a simple indicator such as a scatterplot of confirmed cases against the number of tests can help monitoring the acceleration/deceleration on a daily basis. Other epidemiological outcomes, such as the ratio of number of deaths on the number of confirmed cases could also be used to appreciate the response of health care systems. Such an approach could also be applied to therapeutic innovations, viewed as gains for society, which plays a crucial role in mitigating emerging infectious diseases. In time of crisis, waiting for the results of random clinical trials can often be too long. One can argue that open trials may be more appropriate. One potential indicator for the COVID-19 pandemic would be to consider, on the x-axis, the total number of patients included in the new treatment protocols and, on the $y$-axis, the reduction in the viral load for infected patients after 6 days, compared to that of patients who are or were not treated. A similar procedure could also be applied for major side effects. This would allow health authorities to start treating patients without waiting for the results of a clinical trial, while monitoring in real time the instant progress (or failure) of a new treatment, across countries.

\section{Conclusion: Increasing International Efforts for Coherent Data Collection and Real-} Time Analysis

Our approach is worth being implemented in low-income countries, especially in Africa, where the pandemic is still at an earlier stage but with potential disastrous health and economic impacts if public health decision-making does not follow an appropriate and timely sequence. European and North American countries that opted for various forms of lockdowns by about mid-March expect to see significant changes in the dynamics of the

\footnotetext{
${ }^{5}$ Our approach can be similarly applied to detect acceleration of harm from other major risks such as climate change or biodiversity loss as well as identification of acceleration of gains due to additional knowledge for guiding priority setting for public and private R \& $D$.
} 
pandemic as the incubation period since lockdown expires. They will have to start thinking rapidly about the next measures to be undertaken to lead countries out of their lockdown to avoid enormous economic costs. This obviously needs to be done in a way that protects the most vulnerable people of the respective countries, including those who may need to stay in observed isolation, and those who need to be taken care of, psychologically and financially. Human tragedies need to be avoided even if the economy starts to recover and vice versa. This requires a continued effort of testing with a screening strategy that will allow detecting acceleration of harm on a geographically fine-tuned level and to adapt health policy responses in real time. To be able to do so, accurate and comprehensive data collection is necessary. Successful policy responses to curb the pandemic necessitates cooperation at all levels for data collection, from laboratories and hospitals to continued updating and data exchange at an international level.

\section{References:}

Banerjee, A. X. Guo, and H. Wang (2005): "On the optimality of conditional expectation as a Bregman predictor," IEEE Trans. on Information Theory, 51: 2664-2669.

Degoulet, M., L. Willem, C. Baunez, S. Luchini, P.A. Pintus (2020): "Sensitivity to Rare and Extreme Events in Rats: The Black-Swan-Avoidance Bias", forthcoming bioRXiv and Aix-Marseille School of Economics working paper, April 2020.

Ferguson, N., et al (2020): "Impact of non-pharmaceutical interventions (NPIs) to reduce COVID-19 mortality and healthcare demand", March 16, 2020, available at https://www.imperial.ac.uk/media/imperial-college/medicine/sph/ide/gida-fellowships/ImperialCollege-COVID19-NPI-modelling-16-03-2020.pdf.

Gautret et al. (2020): "Hydroxychloroquine and azithromycin as a treatment of COVID-19: results of an open-label non-randomized clinical trial", International Journal of Antimicrobial Agents, doi:10.1016/j.ijantimicag.2020.105949.

Harrel, F.Z. Jr (2015). Regression Modeling Strategies: With Applications to Linear Models, Logistic and Ordinal Regression, and Survival Analysis. Springer.

Savitzky, A., and Golay, M.J.E. (1964). "Smoothing and Differentiation of Data by Simplified Least Squares Procedures". Analytical Chemistry. 36 (8): 1627-39.

Shen C., N. N. Taleb, and Y. Bar-Yam (2020): "Review of Ferguson et al "Impact of nonpharmaceutical interventions...", March 21, 2020, New England Complex Systems Institute.

Taleb, N. (2012). «Antifragile, things that gain from disorder». Random House.

Wilder-Smith, A., and D.O. Freedman (2020): "Isolation, quarantine, social distancing and community containment: pivotal role for old-style public health measures in the novel coronavirus (2019-nCoV) outbreak", Journal of Travel Medicine, 27: 1-4.

Wu, J.T., K. Leung, G.M. Leung (2020): "Nowcasting and forecasting the potential domestic and international spread of the 2019-nCoV outbreak originating in Wuhan, China: a modelling study", The Lancet, 395: 689-97. 
Wu, Z., and J.M. McGoogan (2020): "Characteristics of and Important Lessons From the Coronavirus Disease 2019 (COVID-19) Outbreak in China. Summary of a Report of 72314 Cases From the Chinese Center for Disease Control and Prevention", published online at: https://jamanetwork.com/journals/jama/fullarticle/2762130?appld=scweb, last access March 25, 2020.

Zhou F, Yu T, Du R, Fan G, Liu Y, Liu Z, et al (2020): “Clinical course and risk factors for mortality of adult inpatients with COVID-19 in Wuhan, China: a retrospective cohort study", The Lancet, doi: 10.1016/S0140-6736(20)30566-3.

\section{Appendix A:}

In the table below we report the data sources and time range, used for Figure 2:

\begin{tabular}{|c|c|c|}
\hline Country & Website & Time range \\
\hline $\begin{array}{l}\text { Austria and Lower Austria } \\
\text { Austrian Broadcasting (ORF) and } \\
\text { Federal Goverment of Lower Austria }\end{array}$ & $\frac{\text { www.orf.at }}{\text { www.noe.gv.at }}$ & $\begin{array}{l}\text { Feb 25-March } 24 \\
\text { March } 1 \text { - March } 24\end{array}$ \\
\hline $\begin{array}{l}\text { Belgium } \\
\text { Federal Service for Public Health, Food } \\
\text { Safety and Environment }\end{array}$ & https://www.info-coronavirus.be/ & Feb. 5-Mar. 21 \\
\hline $\begin{array}{l}\text { Czech Republic } \\
\text { Czech Republic Ministry of Health }\end{array}$ & https://onemocneni-aktualne.mzcr.cz/ & Mar. 1- Mar. 22 \\
\hline $\begin{array}{l}\text { France } \\
\text { National Agency of Public Health }\end{array}$ & www.santepubliquefrance.fr & Feb 28-March 23 \\
\hline $\begin{array}{l}\text { Iceland } \\
\text { Directorate of Heath }\end{array}$ & https://www.covid.is/ & Feb 28-March 23 \\
\hline $\begin{array}{l}\text { Italy } \\
\text { Department of Civil Protection }\end{array}$ & http://www.protezionecivile.gov.it/ & Feb 25-March 21 \\
\hline $\begin{array}{l}\text { Japan } \\
\text { Ministry of Health, Labour and Welfare }\end{array}$ & https://www.mhlw.go.jp/ & Feb 11-March 22 \\
\hline $\begin{array}{l}\text { Norway } \\
\text { VG Broadcasting }\end{array}$ & https://www.vg.no/ & Mar. 12-Mar. 23 \\
\hline $\begin{array}{l}\text { Poland } \\
\text { Ministry of Health, }\end{array}$ & https://www.gov.pl/ & March 3-March 22 \\
\hline
\end{tabular}




\begin{tabular}{|l|l|l|}
\hline $\begin{array}{l}\text { Russia } \\
\text { Federal Service for Surveillance on } \\
\begin{array}{l}\text { Consumer Right Protection Human } \\
\text { Wellbeing }\end{array}\end{array}$ & https://rospotrebnadzor.ru/ & March 5-March 22 \\
\hline $\begin{array}{l}\text { South Korea } \\
\text { Korea Center for Disease Control and } \\
\text { Prevention }\end{array}$ & https://www.cdc.go.kr/ & Jan 21-March 23 \\
\hline $\begin{array}{l}\text { United Kingdom } \\
\text { National Health Service } \\
\text { Government }\end{array}$ & $\begin{array}{l}\text { https://www.nhs.uk/ } \\
\text { https://www.gov.uk/ }\end{array}$ & Feb 27-March 23 \\
\hline
\end{tabular}

